\title{
The Influence of Soil Humidity Stress on Eggplant Crop
}

\author{
Gicuța SBÎRCIOG*
}

Research and Development Institute for Vegetable and Flower Growing Vidra

*)Corresponding author, e-mail: ralldom@yahoo.com

BulletinUASVM Horticulture 74(1) / 2017

Print ISSN 1843-5254, Electronic ISSN 1843-5394

DOI:10.15835/buasvmcn-hort:12057

\begin{abstract}
The reduced soil humidity level has detrimental irreversibile effects on the eggplant crop, by massive abortion of flowers and qualitative fruit spoilage.To establish the soil humidity threshold favorable soil humidity for this crop a series of experiments which followed the interaction soil-water-plant-climate under optimal supplying and various water stress level conditions were carried out of which some results are being presented here on the interaction soil-water-plant-climate, under conditions of optimal supplying and at various water stress levels. The first results led to following conclusions: eggplant crop prefers balanced soil humidity regime, not lower than 60 $\%$ of the range of available water content, being however not higher than the normal field capacity of soil (below $90 \%$ moisture ceiling of AWC);under certain environment conditions (60\% moisture ceiling of AWC) the soil humidity level favourizes relevance of soil productive potential.
\end{abstract}

Keyword: eggplant, humidity, production, soil

\section{Introduction}

In order to meet the consumption requirements, according to the crops destination and way of preparing the fruits, the eggplant breeding process aims at obtaining some cultivars properly adapted to the climate and soil conditions from different areas (Tudor et al., 2004). The climate changes over the last years have determined the orientation of the research programmes towards the selection of genotypes which are resistant / tolerant to the thermal and hydric stress, while preserving the quality traits and production potential. In this context, the selection of genotypes which are tolerant to the thermal and hydric stress represents a major objective of the eggplant breeding activity (Saleh and Saud,1995).

\section{Aims}

The reduced soil humidity level has detrimental irreversibile effects on the eggplant crop, by massive abortion of flowers and qualitative fruit spoilage. The experiences were aimed at establishing favorable soil moisture threshold for culture eggplant

\section{Materials and methods}

It is a bi-factorial experience, where factor $A$ is represented by the variety of humidity regime (A1-60\% moisture ceiling of AWC , A2$90 \%$ moisture ceiling of AWC, using as control A3- non-irrigated) and factor $B$ is represented by by the two cultivars of eggplants (B1-'Luiza' and B2-'Eleonora') placed in subdivided plots. In order to establish the production potential of the two eggplants cultivars, yield was recorded in dynamics, by determining the total average yield ( $\mathrm{t} / \mathrm{ha}$ ) and relative yield (\%). The production data were statistically processed by using the analysis of variance, while the level of significance of the production differences was established by means of the difference limit (Ciulca, 2002).

\section{Results}

From the results of production determined by the interaction of factor A- increase gradually 
Tab. 1. The influence of soil moisture on the production of eggplants

\begin{tabular}{|c|c|c|c|}
\hline Soil moisture/Variety & Average yield (t/ha) & $\begin{array}{l}\text { Difference } \pm \text { as compared to control } \\
\text { (non-irrigated) } t / \text { ha }\end{array}$ & Significance \\
\hline \multicolumn{4}{|l|}{$\begin{array}{c}\text { A1- 60\% moisture ceiling of } \\
\text { AWC }\end{array}$} \\
\hline Luiza & 41.0 & 29.67 & $* * *$ \\
\hline Eleonora & 39.1 & 29.77 & $* * *$ \\
\hline \multicolumn{4}{|l|}{$\begin{array}{c}\text { A2-90\% moisture ceiling of } \\
\text { AWC }\end{array}$} \\
\hline Luiza & 38.67 & 27.34 & $* * *$ \\
\hline Eleonora & 37.67 & 28.34 & *** \\
\hline \multicolumn{4}{|l|}{ A3-Control (non-irrigated) } \\
\hline Luiza & 11.33 & - & - \\
\hline Eleonora & 9.33 & - & - \\
\hline
\end{tabular}

LSD $5 \%=3.19 \mathrm{t} / \mathrm{ha} \quad \operatorname{LSD} 1 \%=4.47 \mathrm{t} / \mathrm{ha} \quad$ LSD $0,1 \%=6.32 \mathrm{t} / \mathrm{ha}$

Tab. 2. The influence of cultivar on the production of eggplants

\begin{tabular}{|c|c|c|c|}
\hline Variety & $\begin{array}{c}\text { Average yield } \mathrm{t} / \\
\text { ha }\end{array}$ & Difference \pm as compared to control (non-irrigated) t/ha & Significance \\
\hline 'Luiza' & 39.04 & \multirow{2}{*}{3.11} & $* *$ \\
\hline 'Eleonora' & 35.93 & & - \\
\hline
\end{tabular}

soil moisture level, results distinct differences. Thus, variants which we performed the minimal humidity $60 \%$ of the AWC, have achieved an average production of $40.05 \mathrm{t} / \mathrm{ha}$ (Luiza-41.0 t / ha; Eleonora-39.1 t / ha), with a difference of 29.72 t / ha compared control (non-irrigated); variants which we performed the minimal humidity $90 \%$ of the AWC, have a difference of $29.72 \mathrm{t} /$ ha compared control -non-irrigated (tab. 1) Concerning the manifestation of the biological potential of the variety, determined by the soil moisture was found significant differences in favor of 'Luiza' variety, more tolerant to water stress (tab. 2).

\section{Conclusion}

Eggplant crop prefers balanced soil humidity regime, not lower than $60 \%$ of the range of available water content, being however not higher than the normal field capacity of soil ( below $90 \%$ moisture ceiling of AWC).

Under certain environment conditions $(60 \%$ moisture ceiling of AWC) the soil humidity level favourizes relevance of soil productive potential. In the present case, the 'Luiza' variety was more resistant to hydric stress than 'Eleonora'.

\section{REFERENCES}

1. Ciulca S (2002). Tehnică experimentală. Editura Mirton. Timișoara.

2. Saleh B, Saud MS (1995). Morphological and Physiological Responses of Eggplant Cultivars (Solanum melongena L.) to Drought. Journal of King Abdulaziz University, Vol. 6, pp. 41-47.

3. Tudor M, Floarea Burnichi, Dorina Jilcu (2004). Analiza producției unor hibrizi de pătlăgele vinete în câmpul de culturi comparative. Anale I.C.D.L.F. Vidra 2004, XVII: 25-29. 